\title{
Ssciendo
}

Ethics \& Bioethics (in Central Europe), 2019, 9 (1-2), 27-35

DOI:10.2478/ebce-2019-0010

\section{Effective altruism for the poor}

\author{
Jakub Synowiec ${ }^{1}$
}

\begin{abstract}
The aim of the paper is to contribute to the debate on effective altruism. It is an attempt to present it as a universal moral proposition - not only a new charity model for the richest citizens of the world. The article starts with a definition of a hypothetical group of relatively-poor effective altruists. Their hypothetical living conditions and opportunities are juxtaposed with the theory of effective altruism developed by Peter Singer and William MacAskill and with career guides proposed by 80000 hours.org - one of the websites gathering effective altruists. In the last part, selected practices for relatively poor effective altruists are described. The conclusion of the paper is, that although most of the reflections behind the concept of effective altruism are developed for the richest people in the world, it is a universal ethical position that can be applied into lives of relatively poor people, whose contribution should not be underestimated.
\end{abstract}

Keywords: effective altruism, Singer, MacAskill, ethical career

\section{Introduction}

Effective altruism is in danger of becoming classified as an "option for the rich" because of the focus on a range of new or enhanced approaches to managing one's donation budget, especially in the beginning of the development of the movement, magnified by the media attracted to the somewhat controversial concept of "earn to give" as a suggested lifestyle choice for supporters of the movement. And, since a significant number of intellectuals supporting effective altruism recommend the level of giving not exceeding what one can give without sacrifice, it seems to be a proposal only for people with deep pockets.

My experience of explaining effective altruism to people from a society that steadily grows economically and tends to be affluent is that arguments made to convince those people earning in any leading developed country, like the United States or the United Kingdom to factor ethical factors in when reconsidering the budget are not that appealing for those who manage their budgets in less wealthy countries. A similar objection can be made about Effective Altruism's advice on ethical career choices, for many reasons, they are tailored to people from the most prosperous countries. This can lead people to treat effective altruism as an idea only for the richest (just as people used to think about charity in general). The main thesis of this paper is to illustrate that effective altruism is a universal ethical proposition, but putting it into practice can take various forms, depending on the circumstances of one's life, and although the guidelines for effective altruists are made for citizens of the most affluent societies, one can adjust them to different conditions with careful reasoning.

To show that effective altruism does not have "property qualification". I focus on "relatively poor effective altruists" - a group of people who cannot reasonably donate $10 \%$ of their income, but at the same time they do not face extreme poverty and would like to do the most good they can. ${ }^{2}$ I intentionally omit people living in extreme poverty, first and foremost

\footnotetext{
${ }^{1}$ The Pontifical University of John Paul II in Krakow (Poland); email: jakub.synowiec@upjp2.edu.pl

${ }^{2}$ This is a hypothetical group which does not refer to any existing society and for the aim of this paper it can actually be an empty set. The philosopher William MacAskill emphasizes that people tend to underestimate their "real power" and focus on their feelings and for that reason they sometimes honestly believe they are in the hypothetical group, whereas they can actually donate $10 \%$ of their income (MacAskill, 2015a, p. 20). It can be rationally assumed that the group of "relatively poor effective altruists" is not an empty set, they might actually be a large group of people who are able to live without external assistance but are not wealthy enough to spend a lot on things which are not related to their basic needs. Based on my personal experience I assume that in countries of central Europe there are many people that could be regarded as members of this group.
} 
because I believe that the topic "ethical duties of people living in extreme poverty" will soon be a hypothetical problem - thanks to advancements in technology and the moral development of humanity (including effective altruism) - and secondly because it would require going into debate on duties in extreme situations, which would exceed the limits of this paper. The conclusion is that even people with limited financial resources and little hope for improving their economic situation, can be effective altruists and do a lot to make the world a better place.

I will start by analysing the idea of effective altruism presented in the works of William MacAskill and Peter Singer, two of the most influential and prominent philosophers supporting effective altruism. The paper then goes over ethical career recommendations proposed by 80000 hours.org $^{3}$ and how they compare with the circumstances of the lives of relatively poor effective altruists. In the next part selected recommendations of effective altruism for everyday life are presented and from that I try to extract what can apply to relatively poor effective altruists in terms of effectiveness.

\section{Doing the most good one can}

Effective altruism, both as an idea and as a movement, was born in affluent societies for their members. ${ }^{4}$ It is primarily a proposition for people who do not have to struggle to satisfy their basic needs, rather they spend huge amounts of their money on things they do not really need and are wealthy enough to save some money. Although all people are equal, some were lucky to be born in rich societies and have an opportunity to do a lot of good with the resources they are able to control. However, effective altruism appears to be a universal proposition since its fundamental idea: the duty to do the most good, is shared by everyone. ${ }^{5}$ The circumstances modify how this general rule is to be put into practice.

The fundamental idea of effective altruism is optimizing the world - for an individual to do the most good. Good appears to be understood in a hedonistic sense, and since the most prominent intellectuals supporting effective altruism are negative utilitarians, they aim to reduce suffering rather than increasing total happiness (as long as there is so much suffering in the world). On the basis of research, effective altruists believe that to optimize costeffectiveness, it is recommended to reduce suffering by indirect action: donating to proven, highly effective charity organizations. ${ }^{6}$ Effective altruism developed meta-charity, which focuses on analysing charity programs in order to be able to recommend those that can do the most good with the given amount of money. Also, there is a huge evidence-guided philosophical

\footnotetext{
${ }^{3} 80000$ hours.org is a part and a founder of the effective altruism community, a nonprofit organization incubated by the Center for Effective Altruism (Oxford), running a website designed to "help as many people as possible lead high-impact careers" by providing career advice.

${ }^{4}$ The genesis of effective altruism can be found in the writings of Peter Singer, a prominent contemporary moral philosopher, starting from his article Famine, Affluence and Morality (Singer, 1972), through more than 40 years of his research and other writings, crowned by his The life you can save (Singer, 2009), where he promotes ethical lifestyle very similar to effective altruism and gives the philosophical arguments for helping the poor. He popularizes the term "effective altruism" in his talk at a TED conference (Singer, 2013) and finally writes a book The most good you can do (Singer, 2015), which is one of the most important books presenting ideas of effective altruism. Singer addresses his writings on poverty to the members of rich societies, who maintain the consumer lifestyle, but in his books on ethical theory he emphasizes that ethics is universal. Another source of effective altruism are the people gathered around the Center of Effective Altruism in Oxford (founded 2011, establishing this center is also probably the first public use of the term), the web pages Givingwhatwecan.org and 80000hours.org and Prof. William MacAskill, who wrote another noteworthy book: The most good you can do (MacAskill, 2015a), which explains the idea and the movement. They also focus on popularizing the idea in the richest societies.

${ }^{5}$ A duty to optimize the world is one of the consequences of utilitarian ethics, which claim to be universal (Singer, $1997 ; 1979 ; 2015)$.

${ }^{6}$ As long as the cost-effectiveness of indirect action(s) is higher than in the case of direct work.
} 
discussion among effective altruists on the areas where the donations should be directed first. ${ }^{7}$ Supporting the recommended most effective organizations gives the donors some security that their money is not being wasted.

However, taking this perspective, the amount of good we can do is obviously related to the amount of money we donate. Effective altruists do not have a universal standard for the amount of their wealth that they should give, but there are some indicators that $10 \%$ is a minimal requirement for the majority of them. One of the popular meta charity advisers - Giving what we can - among other data, shows how many healthy years of life can one grant by $10 \%$ of the household's income. ${ }^{8}$ The $10 \%$ donation as a standard, may have its roots in the writings of Peter Singer, who recommends giving $10 \%$ of the family's income to the poor as a reasonable standard for the majority of the (well-off) people in his most famous book Practical ethics (Singer, 1979, p. 181), alongside the argument that not helping the poor is, for every affluent individual, morally close to the murder of an innocent person (Singer, 1979, pp. 161-168). Increasing the amount of money donated increases the number of lives saved or the amount of eliminated suffering.

For Singer, the logical limit of increasing our donation is somewhere near the margin utility - putting oneself in conditions similar to those we help, but with the ability to function in a rich society and earn money for further donations (Singer, 2015, p. 28). Reducing financial needs, living on less and less to do more good is a possible option, but - as Singer states - promoting it would be counterproductive. People are not rational enough to hold this standard, they are unlikely to try to take an impartial point of view and count the similar interests of others as the same as theirs. There is a natural tendency to promote the interest of people related to us towards the unknown, of our beloved ones and first and foremost of ourselves. ${ }^{9}$ The idea of giving everything above the minimal level of well-being in a society of consumerism is unlikely to be adopted, giving that much could make donors unhappy or even put them outside that society. Peter Singer claims, though, that in exchange, a donor would give his life extraordinary meaning and feel happiness, like many people and he himself do (Singer, 2015, p. 97). In the consumers' society logic ten percent of one's income for happiness and sense of fulfilment is more like a good deal. From a utilitarian perspective, it is better to advocate for a standard that will be widely accepted and has the potential to make the largest possible change towards to good direction, than for the universal moral standard (Singer, 2009, pp. 152-152).

\section{Ethical career choices}

Living on less, on some level, would be too difficult, but there is another way conducive to giving more money. Effective altruists gathered around the website 80000hours.org promote a strategy of doing the most good based on ethical career choices. Even a brief read of The Most Good You Can Do or Doing Good Better reveals that the authors are writing for a particular audience: people from affluent societies. ${ }^{10}$ It also appears that the guidelines for an ethical

\footnotetext{
${ }^{7}$ At the moment, they are: eradication of extreme poverty, eliminating animal suffering and preventing extinction of earth-originated intelligent life. Individual value judgments of effective altruists make them decide which cause they personally feel is the most urgent. There is a powerful argument by Nick Bostrom that existential risk prevention should be the most important cause, as even a little progress in this field outweighs (in terms of doing the most good) anything we can do now, even in areas like eliminating world's poverty. (Bostrom, 2013) but for Peter Singer, although the logic of the argument is correct "it is not an argument that many people are likely to act on" (Sosis, 2019). (The methodology of choosing causes is presented in MacAskill, 2015a, pp. 222-242; Singer, 2015, pp. 117-147).

${ }^{8}$ Givingwhatwecan.org.

${ }^{9}$ These topics are explored by Peter Singer in his The Live You Can Save (Singer, 2009, pp. 45-60).

${ }^{10}$ For example MacAskill writes to a "typical citizen of the west" (MacAskill, 2015a, p. 27) or he supposes that readers of his book are, like him, among "the richest 10\% of the world's population" (MacAskill, 2015a, p. 28). He emphasizes that being among the ten percent of the richest nowadays is an unusual opportunity to do a lot of good.
} 
career offered by effective altruists are adequate for people living in specific conditions in affluent countries. ${ }^{11}$ Currently, 80000 hours.org proposes four approaches to consider: earn to give, advocacy, research and direct work. At the beginning of effective altruism, there was probably too much focus on the "earn to give" strategy, which attracted attention to the movement but also might have created the image of it as limited to "redistribution of wealth". ${ }^{12}$ Although it is certainly the wrong image, the "earn to give approach" is often associated with effective altruism and is still promoted as a way to make a great impact. It also has another advantage: one can easily estimate how much good one has done, for instance, how many vaccines were bought or how many lives were saved (according to MacAskill, donating \$3400 is equivalent to saving one life (MacAskill, 2015a, p. 63), with other approaches it is more difficult. Saving one person in a lifetime can be the most memorable story of a life, but it depends on luck to be in the right place at the right time, and with proper qualifications. However, with the "earn to give strategy", an affluent person can feel like a superhero, saving lives while sitting in an armchair, with a few clicks. The "earn to give strategy" is also somewhat the least demanding one. If one feels content with their job, they just do the ordinary activities by which they earn money to be donated, and without any other activity but following the guidelines of meta-charities, they save lives. Knowing that these ordinary activities are to get money to save lives makes them definitely more important.

Since for some causes, like eradicating extreme poverty, the best impact is available for those with the deepest pockets, the best solution seems to be to become one of them. It is actually a typical aim for most people in a consumer society - land a high-paying job, to earn more, to afford more, to consume more. Effective altruists would use the same means to a different end: get a better-paid job, to earn more, to be able to give more, to do the most good you can. Promoting the "earn to give strategy" may encourage people who do not share consumerist values and are satisfied with a modest level of living, to join the race for the best career. If they are talented enough, they can take the best-paid position available, for ethical reasons.

At first glance, "earn to give" appears to be the best strategy, particularly when we think about people like Bill Gates or Matt Wage, a student of Peter Singer, who was moved by philosophical arguments and instead of continuing his career at Oxford, took a position on Wall Street because that way he would earn far more than as an academic, and, as a result, save more lives (Singer, 2015, pp. 3-4). Obviously, this approach is not suitable for everyone (Todd, 2017c), but it's also society-dependent - i.e. the highest-paying positions are more numerous and more easily accessible in the most prosperous countries. People who are unable to donate $10 \%$ actually have enough motivation to seek a better-paid job, but even getting a relatively good job in a poor society might not put a person close to the salary of an average worker in the most affluent countries. Salaries are also a reason for economic migration, which may drain poorer societies of the best educated specialists. Abandoning positions important in their society in order to work in a more affluent society to take the "earn to give" approach by a person who is hard to replace, can do more harm than good. A medicine specialist in an affluent society is, at best, just an additional worker of his kind, but may also simply make another, less skilled

\footnotetext{
${ }^{11}$ One of the members of 80000 hours.org, Robert Wiblin, admits on "Effective Altruism Forum" that the question what people from poorer countries can do to have a big social impact is difficult for the organization. He presented several ideas, some of them overlap with ideas presented in this paper, but the post is very general, rather to start a debate than to give answers (Wiblin, 2015b).

12 80000hours.org attempts to change this opinion. In an article published on this web page, William MacAskill says it was a mistake to allow journalists to focus on "earn to give". He writes "we used to believe that at least a large proportion of people should aim to earn to give long-term" and puts several, rational and evidence-based reasons why they believe fewer people should take this approach. Among them that there is a greater need for talent than money at the moment (MacAskill, 2015b). However, there is an open question on how much initial focus on the "earn to give" strategy influenced the image of effective altruism in general, and whether it can be reversed.
} 
person, change his job, but in areas where specialists of that kind are scarce, he is precious and needed. ${ }^{13}$ Also, the number of well-paid jobs is limited; getting them requires not only determination but also skills and expertise that are hard to develop under some circumstances. All this means that the "earn to give" strategy may be difficult or not worth the effort in the case of a "relatively poor effective altruist". But there are other possibilities for doing the most good.

Approach number two, recommended by 80000hours.org is advocacy, namely "the promotion of solutions to pressing problems" (Todd, 2017b). Advocacy can accompany virtually every job, and all effective altruists should take part in it (Singer, 2015, p. 4; MacAskill; 2015a, pp. 246-247). Whenever one encourages people to effective altruism, they actually do advocacy. If one donates $10 \%$, and a colleague of theirs, following their example, also decides to donate $10 \%$, then it is more good than without his advocating, and since one can influence many people, part time advocacy can do more good than the full-time "earning to give" 14 (It can be true even for the richest, since people are more influenced by the members of their reference group). Some people can be lucky and have an enormous impact via advocacy, such as politicians, religious leaders or exceptional philosophers whose ideas changed the world, among them, definitely Peter Singer and William MacAskill, but one cannot rationally suspect that he/she will be a prominent philosopher. Taking a rational approach to advocacy led 80000hours.org to suggest trying: political and policy-making positions, position with a public platform, managers and grant makers or professional positions that create favourable conditions for meeting lots of influential people (Todd, 2017a). All these suggestions are for people from affluent nations, but the advocacy approach can be taken by everyone. The more likely to be influential a job is, the more good one can do by advocacy. Teachers, physicians, journalists and other traditional jobs with social impact are probably more valuable in societies with fewer professionals in these areas.

The third recommended approach of doing the most good is a research career. If one can take this career, choosing the right field enables us to do a lot of good as a researcher, for example, taking part in discovering a cure for a serious disease is a big step towards a better world. Technological advancements can also be very helpful - like a tool to deflect asteroids. Research on the effectiveness of charity programs can also do a lot of good because it may help to make donations even more effective (Singer, 2017, p. 58). It appears, though, that going into science is potentially more effective in the most prosperous nations because of the development of education there. Relatively poor effective altruists must carefully consider if they are able to do a lot of good that way.

Direct work is the fourth approach promoted by 80000 hours.org. It is an obvious way of helping but also one that requires caution because there are already many people working that way, so an additional person would not have a great impact and, owing to the fact that charity organizations differ, the best ones are claimed to be a hundred times more effective than the good ones (MacAskill, 2015a, pp. 1658-1662). And there are also harmful ones. Getting a post in an aid agency is reasonable for a person who cannot earn enough to donate the amount of money necessary to hire an aid worker and feels good about doing that job. It is also good for those people who feel a desire to help directly. People in the most affluent countries who do not feel personal commitment to this job are advised to take a different one because they can be replaced by other persons in these jobs and if they opt for "earn to give" instead, they can "hire" several aid workers thanks to their donations. For relatively poor effective altruists, direct work can be as good as another career but it also allows them to do good by direct actions. Exceptional individuals can achieve a lot by starting charity organisations (Singer, 2015, pp. 58-62).

\footnotetext{
${ }^{13}$ These thoughts were inspired by MacAskill's recommendation to not take up a career as a doctor in an affluent society (MacAskill, 2015a, pp. 90-91).

${ }^{14}$ Peter Singer encourages the showing of one's noble acts, because it can inspire others to do more good: "we are much more likely to do the right thing if we think others are already doing it” (Singer, 2009, pp. 64-68).
} 
What is more, 80000 Hours.org presented which positions that can be regarded as the most harmful and therefore should be avoided (Wiblin, 2015a). People ought to choose another career path for ethical reasons. The list of the ten most harmful jobs include positions held by many people worldwide: marketing for compulsive behaviours (alcoholism, gambling, etc.), factory farming, fraudulent medical technologies (homeopathy), "patent trolling", lobbying for rentseeking businesses, weapons research, borderline fraudulent lending, fund rising for harmful charities, forest clearing and tax minimization for the super-rich. From this list, the attention of relatively poor effective altruists should be paid to factory farming and forest clearing, as there are many positions in these areas where no sophisticated intellectual skills are required, so anyone can take them. It is unlikely that an effective altruist can do any better when replacing another person who would otherwise take this job, as harming animals and the environment are part and parcel of these jobs. People convinced to effective altruism, even if they do not want or cannot take the "earn to give" approach, should treat the choice of their career path as a moral choice and, if their options are limited, choose a career that is at least not harmful.

It seems that guidelines for careers at 80000 hours.org are made for citizens of affluent countries and may be of little help to people who do not have such opportunities. However, effective altruism "is about asking «how can I make the biggest difference I can» and using evidence and careful reasoning to try to find the answer" (MacAskill, 2015a, p. 15). The conclusion to this part is that effective altruists living in a poorer society or being unable to reach the level of affluence that would allow them to do good by donations, can still treat their career as a moral choice, using reasoning and the best evidence they have. Sometimes, it might turn out that a career which would not be advised in a rich country is the right choice in a poorer country. For instance, MacAskill suggests that the career of a doctor does not have to be the right ethical choice (MacAskill, 2015a, pp. 78-90). He claims there are already many doctors and another one in an affluent country does not bring much good, let alone that normally just replaces another person who would probably be as good a doctor as this one. But when we start thinking about other countries, an extra doctor may be the one who provides people with services otherwise unavailable and benefit poorer society, ${ }^{15}$ thus, careful reasoning can bring us to the conclusion that being a doctor may be doing the most good for some relatively poor effective altruists.

\section{Everyday choices are moral choices}

The principle of "doing the most good one can" led many people to reconsider their careers but, if taken seriously, also means significant changes in the personal life of an individual. Peter Singer presents these changes as a modest life (Singer, 2015, pp. 23-37). Singer suggests that all our consumer choices are moral choices, and therefore, if one is about to buy a car, they shouldn't buy the best one they can afford, but rather the one which would be sufficient to serve their needs (i.e. a small car for commuting in a city). The saved money should be, then, donated. This example is, of course, of no help to people who buy just any second-hand car and hope it will be cheap to maintain. Yet, it can be a guideline for other, maybe smaller choices. Giving careful consideration to consumer choices may lead to the conclusion that even relatively poor people can save money and donate it.

Another idea to be used for less wealthy people is manifesting real care for the suffering of animals in their dietary choices. Eliminating the suffering of animals in factory farms is one of the main causes of effective altruism in people (Singer, 2015, pp. 137-144). Animal-based food was made cheap due to mass production in factory farms and is available even for the poor. On

\footnotetext{
${ }^{15}$ MacAskill presents estimations that an average doctor in the United States will save about 2-4 lives during his entire career by his direct action (which is, undeniably, a great achievement), whereas in Ethiopia it is 300 lives. However, a doctor in the United States is more likely to be able to save more additional people by his donations. MacAskill, 2015a, pp. 78-93.
} 
the other hand, the real costs of cheap meat are incomparable to the profits (Lymbery \& Oakeshott, 2014). Animals kept in factory farms are the only means for factory owners to make a profit, their suffering matters when it decreases profits, therefore they suffer a lot, for some of them death is the best moment of their lives. A meat-based diet is also partly responsible for global hunger and - in the long run - can cause existential risk for our species. ${ }^{16}$ There are several ways of stopping factory farming, but Singer recommends changes in our diets as the most effective one. ${ }^{17}$ If there are no people willing to pay for the products of factory farming, they will stop working, meat will become expensive in shops and thus harder to buy. The effect would be quick and impressive if many people went vegan or vegetarian. William MacAskill argues reasonably, that even the decision of a single person can have a great impact by being the one that would change the amount of meat ordered by a shop (MacAskill, 2015a, pp. 107108). However, going vegan or vegetarian might still be difficult in poorer countries, where cheap meat is a good nutrition option. Another alternative worth considering is to do a lot of good just by preparing meals for our family while practising reducetarianism, in this case: intentional dietary choices which aim to reduce the amount of meat consumed. It can be achieved by meatless days, smaller portions or changing the proportion of meat in a meal. Reducetarianism appears to be more likely to be adopted by society than a strict diet (Kateman, 2017), so it has potential for being more effective than the veg(etari)an approach. Making 10 people reduce their meat consumption by $10 \%$ is the equivalent of making 1 go vegan. Also, there are strong arguments that most effective reducetarianism is to stop eating chicken, eggs and pork first (MacAskill, 2017, pp. 69-71).

Another thing good for effective altruists in any circumstances is to focus on not wasting. Singer recommends cooking at home instead of eating out in restaurants or drinking water from the tap (if it is safe), not from the bottle (Singer, 2009, p. ix). People throw away a lot of edible food, sometimes because they just want to eat something else. There is no direct way to transfer food to distant lands at reasonable costs, but indirectly, one can focus on planning his meals and save some money that way.

\section{Conclusion}

It may turn out that the most effective way of doing good for relatively poor effective altruists is... promoting effective altruism or an ethical life in general. Convincing people to effective altruism can multiply one's impact. And, considering that the people we convinced may keep spreading the idea, one can find oneself in the beginning of a chain of people who will finally become convinced to effective altruism. It is to be noticed that people living in affluent countries are not the only ones to live in extraordinary times. More and more countries are becoming affluent and living standards are going up, as well. Technological development is rapid, and new advances also help people in poorer countries, sometimes they even do better than charity actions. ${ }^{18}$ The world is constantly developing and for that reason we can expect that people in the future will have better opportunities to do good, if they decide to follow "do the most good" rule rather than "do whatever you want", so making them more ethical is a good thing to do. There is no general answer how to be effective in making people more ethical, yet, setting a good example is always the right strategy.

\footnotetext{
${ }^{16}$ Meat production indirectly threats human species by its contribution to the greenhouse effect.

${ }^{17}$ A method of achieving this goal is advocacy for changes in diet (Singer, 2015, p. 139). Peter Singer has been doing it for his entire career. MacAskill argues, that "changing consumption habits is not [a]very effective way compared with the alternatives" (MacAskill, 2015a, p. 178), but here too he focuses on the most affluent people, who can do more good by donations.

${ }^{18}$ A very popular program, One laptop per child, was prepared to provide access to modern technology for people in developed countries, yet, it appears that rapid development of smart-phones achieved this goal without fundraising.
} 
Effective altruism career guides recommend young people to invest in themselves at the beginning of their career, in order to have more to give away later on. If they start identifying with the ideas of effective altruism as students, they might also do so as adults, and acquire the habit of giving before gaining the habit of extensive consumption. The same can be true for groups like citizens of poorer countries. Apart from advancements in technology and great progress in economy, effective altruism was set up because of a great development in moral reflection (Singer, 2015, pp. 13-20). After all, people who started effective altruism had been concerned about the most important moral problems before. Making people ethical before they are able to afford to lead a consumer lifestyle would constitute a vaccine of sorts. An alarming example are countries like China, where the level of wealth has increased and now people want to have the "West-like" access to cheap meat (Shih Han, 2014). Satisfying them would cause more suffering of animals. There would be less demand for cheap meat if the opinion that eating meat was wrong was shared by many people in this society before it became wealthy. The increasing prosperity in China may also worsen the greenhouse effect, which is a potential threat to humanity. The rising level of affluence is also good news, for there will be more people with the capability to make donations. Even if in a given country most people are relatively poor, it does not mean it would never change, estimating their impact should include reflection on what they would probably be able to do in the future. When new opportunities to do the most good arise, effective altruists will be prepared and, instead of increasing their consumption, they would use them to make the world a better place. Promoting effective altruism is a good goal, also among those who cannot make a great impact at the moment.

Effective altruism is a revolutionary ethical proposition which has attracted the attention of many people, not only from the most affluent countries, although it was clearly made for them in the first place. Our world has recently become smaller but the difference in opportunities and the level of affluence remains high. Using reason and evidence to do the most good one can is a principle for everyone. There are guidelines provided by intellectuals supporting effective altruism, some of them intentionally vague, to cover many potential examples, but as it was emphasized, they are also tailored to people living in the most prosperous countries and do not match the circumstances of living of those "relatively poor effective altruists". A task for local effective altruism communities, which are emerging even in very poor countries, is to adjust the reflection of effective altruism to those realities specific to their area, considering the available facts in careful reasoning.

\section{References}

BOSTROM, N. (2013): Existential risk prevention as global priority. In: Global Policy, 4(1), pp. 15-31.

KATEMAN, B. (ed.) (2017): The reducetarian solution. New York: Tarcherperigee.

LYMBERY, P. \& OAKESHOTT I. (2014): Framageddon: The true cost of cheap meat. London: Bloomsbury Publishing.

MACASKILL, W. (2015a): Doing good better: Effective altruism and a radical new way to make a difference. London: Guardian Books.

MACASKILL, W. (2015b): 80,000 hours thinks that only a small proportion of people should earn to give long term, in: 80000hours.org, published 06.07.2015, edited 12.07.2015. [online] [Retrieved April 29, 2019] Available at: https://80000hours.org/2015/07/80000-hours-thinksthat-only-a-small-proportion-of-people-should-earn-to-give-long-term

MACASKILL, W. (2017): Effective reducetarianism. In: B. Kateman (ed): The Reducetarian solution. New York: Tarcherperigee, pp. 69-71.

SHIH HAN, T. (2014): China's demand for meat to change the face of global trade in feed grains. In: South China Morning Post, published: 20.05.2014. [online] [Retrieved April 29, 
2019] Available at:http://www.scmp.com/business/commodities/article/1516060/chinassoaring-demand-meat-change-face-global-trade-feed-grains

SINGER, P. (1972): Famine, affluence and morality. In: Philosophy \& Public Affairs, 1(3), pp. 229-243.

SINGER, P. (1979): Practical ethics. New York \& London: Cambridge University Press.

SINGER, P. (1997): How are we to live? Ethics in an age of self-interest. Oxford \& New York: Oxford University Press.

SINGER, P. (2009): The life you can save: Acting now to end world poverty. New York: Picador. SINGER, P. (2013): Why and how to be effective altruist, TED conference, published: 03.2013. [online] [Retrieved April 29, 2019] Available at: https://www.ted.com/talks/peter_singer_the_why_and_how_of_effective_altruism?

SINGER, P. (2015): The most good you can do: How effective altruism is changing ideas about living ethically. New Haven \& London: Yale University Press.

SOSIS, C. (2019): An interview with Peter Singer. In: what is it like to be a philosopher, published without a date of publication, [online] [Retrieved April 29, 2019] Available at: Whatisitliketobeaphilosopher.com, http://www.whatisitliketobeaphilosopher.com/\#/petersinger/

TODD, B. (2017a): What is the best way to become an advocate? In: 80000hours.org, published 04.2017. [online] [Retrieved April 29, 2019] Available at: https://80000hours.org/articles/theadvocate/\#whats-the-best-way-to-become-an-advocate

TODD, B. (2017b): Approach 2: Advocacy. In: 80000hours.org, published 04.2017. [online] [Retrieved April 29, 2019] Available at: https://80000hours.org/career-guide/high-impactjobs/\#approach-2-advocacy

TODD, B. (2017c): Should you earn to give? In: 80000hours.org, published 04.2017. [online] [Retrieved April 29, 2019] Available at: https://80000hours.org/career-guide/high-impactjobs/\#should-you-earn-to-give

WIBLIN, R. (2015a): What are the 10 most harmful jobs? In: 80000hours.org, published: 14.08.2015. [online] [Retrieved April 29, 2019] Available at: https://80000hours.org/2015/08/what-are-the-10-most-harmful-jobs/

WIBLIN, R. (2015b): What if you want to have a big social impact and live in a poorer country? In: Effective Altruism Forum, published 20.12.2015. [online] [Retrieved April 29, 2019] Available at: http://effective-altruism.com/ea/rd/what_if_you_want_to_have_a_ big_social_impact_and/ 